\title{
Okul Öncesi Eğitim Programında Bulunan Eğitim Planlarının Öğretmenler Tarafından Değerlendirilmesi ${ }^{1}$
}

\author{
Dilruba Saygin² Duygu Yalman Polatlar ${ }^{3}$
}

\begin{abstract}
Öz
Bu araştırmada 2013 Okul Öncesi Eğitim Programının sunduğu özelliklerine göre etkinlik planlarının içeriği, hazırlanışı ve uygulanışının öğretmenlerin değerlendirmelerine göre incelenmesi amaçlanmıştır. Araştırmada, nitel araştırma yöntemlerinden Olgubilim (fenomenoloji) deseni kullanılmıştır. İstanbul' un Fatih, Güngören, Bakırköy ilçelerinden toplam 8 anaokulundan 12 okul öncesi öğretmeni çalışma grubunu oluşturmaktadır. Yarı yapılandırılmış görüşme yöntemiyle toplanan veriler, betimsel analiz yaklaşımı ile yorumlanmıştır. Araştırmada "Planlama Süreci", "Okul Yönetiminin Tutumu", "Değerlendirme", "Programların Kiyaslanması" konulu 4 ana tema incelendiğinde, öğretmenlerin bazılarının 2006 Okul Öncesi Eğitim Programının etkisinden çıkılmadığı, hazır plan kullanıldığı, okul yönetiminin eğitim planlarını incelemeden imzaladığı ve eğitim planında yer alan değerlendirme kısımlarının yapılmadı̆̆ı saptanmıştır.
\end{abstract}

\section{Anahtar Kelimeler}

2013 Okul Öncesi Eğitim Programı, eğitim planı, öğretmen

\section{Teacher Evaluation of Education Plans Based On Preschool Education Program}

\footnotetext{
Abstract

1 Bu çalışma, 2018 y1lında Afyon Kocatepe Üniversitesi'nde gerçekleştirilen “13. Okul Öncesi Eğitimi Öğrenci Kongresinde" sunulmuştur.

2 İstanbul Kültür Üniversitesi Lisansüstü Eğitim Enstitüsü Eğitim Yönetimi ve Planlaması Yüksek Lisans Bölümü, Ataköy Yerleşkesi, 34158, İstanbul. E-posta: HYPERLINK "mailto:dlrbsygn@ gmail.com" dlrbsygn@gmail.com, ORCID ID: 0000-0002-7838-8549

3 Yetkilendirilmiş yazar: Duygu Yalman Polatlar, Fatih Sultan Mehmet Vakıf Üniversitesi, Temel Eğitim Bölümü, 34664, Üsküdar, İstanbul. E-posta: HYPERLINK "mailto:duyguyalman@gmail. com" duyguyalman@gmail.com, ORCID ID: 0000-0002-9030-5814
} 
The aim of this study is to examine the content of activity planning, preparation and application in accordance with 2013 Pre-School Education Program in reference to teacher evaluation. The survey was designed using "Phenomenology" from one of the qualitative researches. 12 pre-school teachers participated in the study from Istanbul, the district of Fatih, Gungoren, Bakirkoy. Data was collected by using semi structural interview and It was interpreted with descriptive content analysis approach. In the research, when these 4 main theme "Planning Process", "Attitude of School Management", "Evaluation", "Comparing Programs" analyzed, it is examined that some teachers still continue to use plans prepared by other teachers and follow the 2006 Preschool Education Program, in addition, school administration approves the education plans without checking and the evaluation part of the education program is not completed.

\section{Keywords}

2013 Preschool Education Program, education plan, preschool teacher

\section{تقييم خطط التعليم في برنامج التعليم قبل المدرسة من قبل المعلمين \\ ديلروبا سايجين، دويغو يامان بولاتيلار

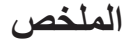

في هذه الدر اسة، يهدف إلى تحقيق محتوى خطط النشاط وفقا للخصائص التي يقدمها برنامج التعليم قبل المدرسة لعام Y • آ و إعدادها وتنفيذها وفقا لتقبيمات المعلمين. في البحث، استخدام

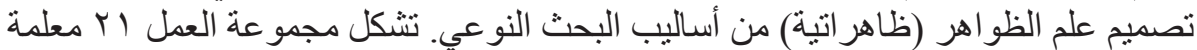

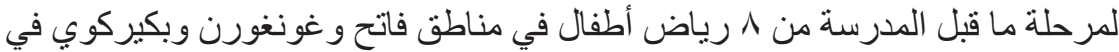

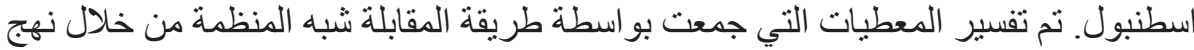

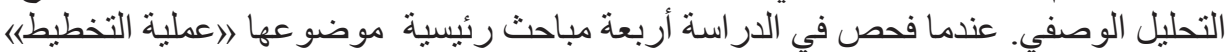

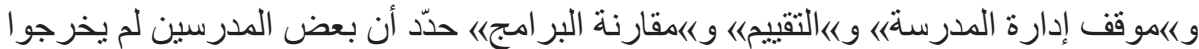

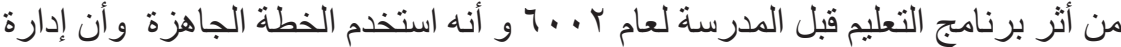

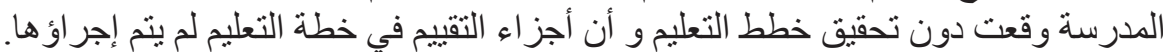

\section{الكلمات الرئيسية}

برنامج التعليم قبل المدرسة لعام r • (اس، خطة التعليم، المعلم 


\section{Giriş}

Okul öncesi eğitim çağı bireyin yaşamındaki en değerli dönemdir dolayısıyla bu dönemde alınacak eğitim de kritik bir öneme sahiptir (Tuncer, 2015). 0-6 yaş dönemi çocuğun gelişim hızı ve öğrenme kapasitesinin en yüksek olduğu kritik yıllardır. Bu dönemde temeli atılan beden yapısı ve kişilik yapısının, ileriki yıllarda aynı yönde gelişme şansı daha yüksektir. Çocukluk yıllarında kazanılan davranışların büyük bir kısmının yetişkinlikte bireyin kişilik yapısını, tavır, alışkanlık, inanç ve değer yargılarını biçimlendirdiği gözlenmiştir (Balcı, Gündoğdu ve Çelik, 2012). Okul öncesi eğitimin birçok açıdan önemli etkileri olduğunu vurgulayan eğitimci Myers (1992), çocukların yaşamaya ve potansiyellerini en üst noktasına kadar geliştirmeye hakları olduğunu ve okul öncesi eğitimin çocuklara bu olanakları sağladığını, insanlık değerlerinin çocuklar yolu ile aktarıldığını ve bu değerlerin geleceğe taşınabilmesi için işe çocuklardan başlanılması gerektiğini, çocuk gelişimine yatırım yaparak, toplumların artan üretim ve maliyet yolu ile ekonomik yararlar sağladığını, sağlık, beslenme, kadın programları gibi diğer toplumsal gelişme çabalarının ancak çocuk gelişimi programlarıyla arttırılabileceğini, okul öncesi eğitim yolu ile tüm çocuklara firsat eşitliği sunularak çeşitli eşitsizliklerin ortadan kaldırılabileceğini, değişen toplum yapısı nedeniyle okul öncesi eğitime olan ihtiyacın çok arttığını vurgulamaktadır (akt. Gültekin Akduman, 2010).

Öğretmenler erken çocukluk eğitiminde en önemli bileşenlerden birisidir (Avc1, 2014). Pasca’ya (1993) göre eğitimin nitelikli bir şekilde yapılabilmesi, uygulayıcısı olan öğretmen ile doğrudan bağlantılıdır (akt. Koçyiğit, 2010). Öğretmenlerin eğitimdeki önemi, Bronfenbrenner'in Ekolojik Sistemler Kuramında da görülmektedir. Bu kuram, çocuğun içinde yaşadığı pek çok kurumun ve ortamın gelişim üzerindeki etkisine vurgu yapmaktadır (Trawick Swith, 2010). Bununla birlikte çocuğun en yakın çevresi olan ve gelişimine doğrudan etki eden mikrosistem katmanında öğretmen de yer almaktadır. Bu bağlamda, öğretmen özellikleri okul öncesi eğitiminin niteliğini ve çocuğun gelişimini etkileyen en temel belirleyicilerden biridir (MEB, 2013).

Okul öncesi eğitim kurumlarından çocuğun beklenilen düzeyde yararlanabilmesi ve öğretmenin verimli olabilmesi, ancak eğitim programının çok iyi bilinmesi ve uygulanmasıyla mümkün olabilir (Kandır, 1999). Bu durum, yaşamın ilk ve en önemli yılları olan erken çocukluk döneminde çalışan okul öncesi öğretmenlerinin profesyonelliğini gerektirmektedir. Profesyonellik, görevlerin yerine getirilmesi için üstün entelektüel eğitim alma, bu eğitim sonucunda bilgi ve tecrübe kazanarak mükemmelliği yakalama ve bireysel ilkeler doğrultusunda deneyimlerini eyleme dönüştürüp özgür etkinlikler yapmaya sahip olmaktır (Raelin, 1999). Katz ve Kodama’ya (1983) göre öğretmen, eğitim için olanaklar hazırlayan ve elde edebildiği olanakları eğitimin amaçlarının gerçekleştirilmesi için en iyi biçimde kullanma görevini üstlenmiş olan profesyonel bir kişidir (akt. Koçyiğit, 2010). Öğretmenlerin profesyonel davranışlar sergilemelerinin öğretimin kalitesinin artıracağı ve okulun işlevlerini daha etkili bir şekilde yerine getirebileceği ifade edilmektedir (Yirci, 2017). 
Alvestad ve Duncan (2006), günlük planların amaçlarına ulaşılmasıyla başarılı olacak erken çocukluk eğitim programlarının en önemli unsurunun nitelikli/ profesyonel öğretmenler olduğunun bir kez daha altını çizmektedir. Örneğin, California eyaletinin öğretmenlik mesleği standartlarında "Profesyonel eğitimci olarak gelişim" maddesi kullanılmıştır (akt. Dağlığlu, 2010). Fakat yapılan araştırmaya göre, Türkiye'de okul öncesi ögretmenleri kuruma katkı ve kişisel gelişim gibi alanlarda kendilerini daha az profesyonel algılarken, duygusal emek boyutunda daha fazla profesyonel algılamaktadır (Altınkurt ve Yılmaz, 2014). Fakat öğretmenlerin her açıdan profesyonel davranması çocukların gelişimleri için büyük önem taşımaktadır. Diğer bir ifadeyle, profesyonel bir öğretmen mesleğinin gerekliliğini yapmalıdır. Okul öncesi dönemde profesyonellik eğitim programlarına uygun planlı çalışmaktır. Diğer bir ifadeyle, okul öncesi eğitimin amaçlarının gerçekleştirilebilmesi iyi planlanmış eğitim programları ile mümkün olabilir (Güven, 2010).

Buna bağlı olarak, Türkiye' de en son güncellenen 2013 Okul Öncesi Eğitim Programı MEB'e bağlı anaokulları ve anasınıflarında kullanılmaktadır. Programın temel özellikleri incelendiğinde, eğitim planının içeriği şu şekildedir; "Çocuk merkezlidir, esnektir, sarmaldır, eklektiktir, dengelidir, oyun temellidir, keşfederek öğrenme önceliklidir, yaratıcılığın geliştirilmesi ön plandadır, günlük yaşam deneyimlerinin ve yakın çevre olanaklarının eğitim amaçlı kullanılmasını teşvik eder, temalar/konular amaç değil araçtır, öğrenme merkezleri önemlidir, kültürel ve evrensel değerleri dikkate alır, aile eğitimi ve katılımı önemlidir, değerlendirme süreci çok yönlüdür, özel gereksinimli çocuklar için uyarlamalara yer vermektedir, rehberlik hizmetlerine önem vermektedir." (MEB, 2013). Bu özelliklere göre, eğitim planı hazırlanırken öğretmenlerden; öğrenme merkezlerinin düzenlenmesi, aylık eğitim planı ve günlük eğitim planının oluşturulması beklenmektedir. Ayrıca çocuk, program ve öğretmen açısından her gün günlük eğitim akışı ve etkinlik planlarıyla; her ay sonu aylık eğitim planı değerlendirilmesi gerekmektedir (MEB, 2013). Başka bir ifadeyle, program öğretmenlerin planlı çalışmalarını gerektirmektedir (Gürkan, 2010). Buna bağlı olarak, programın kalitesi öğretmenin öğrenme ortamını planlama ve yürütme becerilerine bağlıdır (Avc1, 2014). Öğretmenin planlama becerisi, program uygulamalarında öğretmenin daha sistemli çalışmasına ve kendine güven duymasına firsat verecektir (akt. Kandır, Özbey ve İnal, 2007). Öğretmenlerin plan yapmalarının uzantısı olan eğitim süreçlerindeki rollerini vurgulayan Natioanl Board for Teaching Standards (NBPTS, 2016), eğitimde plan yapmadan ve öğrenme ortamını tasarlamadan öğretmenlerin sınıftaki görevini yerine getiremeyeceğini farklı ifadelerle ortaya koymaktadır. Bununla birlikte değerlendirme sürecini de olumlu yönde etkileyerek öğretmen daha nitelikli bir eğitim sunacaktır. Çünkü değerlendirme eğitim sürecinin ayrılmaz bir parçasıdır ve öğretmene çok önemli dönütler sağlar. Öğretmen bu dönütler sayesinde daha sonraki çalışmalarını geliştirme ve daha etkili hale getirme şansına sahip olur (Gürkan, 2010).

Eğitim planlarının uygulamaya olabildiğince yansıtılması ayrı bir önem taşımaktadır. Öğretim programı bir plan, öğretim de bu planı uygulama aşaması olarak tanımlanmaktadır (Demirel, 2013). Buna göre, erken çocukluk dönemi eğitim programı 
tasarılarının uygulama koşullarına uygun hazırlanması, uygulamaya olabildiğince yansıtılması ve değerlendirilmesinde de öğretmenlere büyük bir rol düşmektedir (Ünver ve Erdamar, 2015). Fakat etkinlik kitaplarının yanında verilen ve başkası tarafından toplu olarak hazırlanmış eğitim planlarıyla çalışan öğretmenlerin; bu planları uygulamaya ne şekilde yansıtabileceği tartışılırken, çocukların değerlendirilmeleri istenilen nitelikte olmayacaktır. Buna bağlı olarak, okul öncesi eğitim çağındaki çocuklara kazandırılabilecek her şey planlı olarak ele alınabilirse beklenen yarar sağlanabilir (Güven, 2010) ve bir eğitim programının başarısının onu uygulayacak öğretmenlerin nitelikleri ile sınırlı olduğu gerçeği asla unutulmamalıdır (Gürkan, 2003). Bahsedilen eğitim planının içeriği ve hazırlanışı göz önüne alındığında, bir öğretmenin derse hazırlanmaya verdiği anlam ve derse hazırlanış tarzı, onun mesleki bilincinin önemli bir göstergesidir (Cüceloğlu ve Erdoğan, 2013).

Kaliteli bir okul öncesi eğitim çocukların öğrenme yaşantılarını zenginleştirme, yeteneklerini destekleme, okula devam, ilköğretime başarılı bir geçiş ve okul başarısı sağlama işlevlerinin yanı sıra uzun vadede topluma katkı sağlama olasılıklarını arttırmakta, işsizlik ve yoksulluk gibi sonuçları engellemektedir (Gültekin Akduman, 2010). Okul öncesi dönemde verilecek nitelikli bir eğitimin çocuğun yaşamını şekillendirmek açısından önem taşıdığı bilinmektedir (Kandır, Özbey ve İnal, 2007). Bu niteliği gösteren en önemli unsurlardan bir tanesi çocukların bütün gelişim alanlarına hitap eden eğitim programlarından yararlanmalarıdır. Başka bir deyişle okul öncesi eğitimde uygulanan programların çağdaş yaklaşımları benimsemiş, çocuğu merkeze alan ve alternatif öğretim yöntemlerini destekleyen bir yapıya sahip olması beklenen özelliklerindendir. Bahsedilen bu özelliklerin sınıfta uygulanmasını sağlayacak en etkin kişinin sınıf öğretmeni olduğu gerçeğinden hareketle, eğitim planlarının içeriği, hazırlanışı ve uygulanışı değerlendirilmelidir. Bu çalışmayla birlikte 2013 Okul Öncesi Eğitim Programına göre hazırlanan eğitim planlarının nitel verilerle derinlemesine değerlendirilmesi, öğretmenlerin görüşlerini "kendi ifadeleriyle" incelenmesini sağlamak adına önemlidir. Bununla birlikte okul öncesi eğitim programında uygulanan eğitim planlarının pratik açıdan verimliliği ile ilgili açılımlar sunmaktadır. Elde edilen verilerle gerekirse okul öncesi eğitim programının teorik açıdan yeniden gözden geçirilebileceği düşünülmektedir.

\section{Araştırmanın amacı}

$\mathrm{Bu}$ araştırmada, 2013 Okul Öncesi Eğitim Programının sunduğu olanaklara göre etkinlik planlarının içeriği, hazırlanışı ve uygulanışının öğretmenlerin değerlendirmelerine göre incelenmesi amaçlanmıştır. Bu ana amaç doğrultusunda, aşağıda belirtilen soruların cevapları araştırılmıştır.

1. 2013 Okul Öncesi Eğitim Programına göre öğretmenler planlama sürecini nasıl değerlendirmektedirler?

2. Okul öncesi öğretmenleri plan hazırlama süreçlerinde okul yönetiminin tutumunu nasıl değerlendirmektedirler? 
3. Okul öncesi öğretmenleri aylık ve günlük planlarının değerlendirmesini hangi sıklıkla yapmaktadırlar ve ölçüt aldığı durumlar nelerdir?

4. Geçmişten günümüze okul öncesi eğitim programları kıyaslandığında, öğretmenler hangi MEB programının daha nitelikli olduğunu düşünmektedirler?

Dayanakları nelerdir?

\section{Yöntem}

\section{Araştırma Modeli}

Araştırma, nitel araştırma yöntemi kullanılarak tasarlanmıştır. Nitel araştırma, insanın kendi sırlarını çözmek ve kendi çabasıyla biçimlendirdiği toplumsal sistemlerin derinliklerini keşfetmek üzere geliştirdiği bilgi üretme yollarından birisidir (Özdemir, 2010). Nitel araştırma yöntemlerinden “Olgubilim (fenomenoloji)” deseni kullanılmıştır. Olgubilim araştırmalarında veri analizi, yaşantıları ve anlamları ortaya çıkarmaya yöneliktir. Bu amaçla yapılan içerik analizinde verinin kavramsallaştırılması ve olguyu tanımlayabilecek temaların ortaya çıkarılması çabası vardır. Sonuçlar betimsel bir anlatım ile sunulur ve sık sık doğrudan alıntılara yer verilir. Bunun yanında ortaya çıkan temalar ve örüntüler çerçevesinde elde edilen bulgular açıklanır ve yorumlanır (Yıldırım ve Şimşek, 2013).

\section{Çalışma Grubu}

Araştırmada amaçlı örnekleme yöntemlerinden, kolay ulaşılabilir durum örneklemesi kullanılmıştır. Araştırmanın örneklemine dâhil olan öğretmenler; devlete bağlı bağımsız anaokulları ve ilkokulların bünyesindeki anasınıflarından tercih edilmiştir. Araştırma grubundaki öğretmenler belirlenirken farklı sosyo-ekonomik düzeylerdeki çocuklarla çalışan öğretmenlerin planlama süreçlerinde değişiklikler olup olmadığını öğrenmek adına, çalıştıkları ilçelerdeki okulların alt, orta ve üst sosyo-ekonomik düzeyleri temsil etmesine dikkat edilmiştir. Buna bağlı olarak; İstanbul'un Fatih, Güngören, Bakırköy ilçelerinden toplam 8 anaokulundan 3 kişi alt, 6 kişi orta, 3 kişi üst sosyo-ekonomik düzeyi temsil eden toplam 12 okul öncesi öğretmeni 2018 yılının Ocak ile Mart ayları arasında araştırmaya katılmıştır. Araştırmaya katılan öğretmenler, görüşmelerin gerçekleştirildiği okul sırasına göre numara verilerek kodlanmıştır. Kodlar şu şekildedir, “Ö.1, Ö.2, Ö.3, Ö.4, Ö.5, Ö.6, Ö.7, Ö.8, Ö.9, Ö.10, Ö.11, Ö.12”. 
Tablo1

Araştırma Grubunu Oluşturan Öğretmenlerin Demografik Bilgileri

\begin{tabular}{|c|c|c|c|c|c|}
\hline Cinsiyet & $\begin{array}{l}\text { Yaş } \\
\text { Aralığ1 }\end{array}$ & $\begin{array}{l}\text { Öğrenim } \\
\text { Düzeyleri }\end{array}$ & $\begin{array}{l}\text { Mezun } \\
\text { Olunan } \\
\text { Üniversite } \\
\text { Türü } \\
\end{array}$ & $\begin{array}{l}\text { Mezun } \\
\text { Olunan } \\
\text { Lise Türü }\end{array}$ & $\begin{array}{l}\text { Meslekteki Hizmet } \\
\text { Süresi }\end{array}$ \\
\hline $\begin{array}{l}\text { Kadın: } \\
11 \\
\text { Erkek: } 1 \\
\text { Toplam: } \\
12\end{array}$ & $\begin{array}{l}\text { 20-24 } \\
\text { yaş: } 2 \\
\text { 30-34 } \\
\text { yaş: } 3 \\
\text { 35-39 } \\
\text { yaş: } 4 \\
\text { 40-44 } \\
\text { yaş: } 1 \\
45-49 \\
\text { yaş: } 2 \\
\text { Toplam: } \\
\text { 12 }\end{array}$ & $\begin{array}{l}\text { Ön Lisans: } 1 \\
\text { Lisans: } 10 \\
\text { (2 öğretmen } \\
\text { lisansüstü } \\
\text { eğitimine } \\
\text { devam } \\
\text { etmektedir) } \\
\text { Lisansüstü: } \\
1 \\
\text { Toplam: } 12\end{array}$ & $\begin{array}{l}\text { Vakıf } \\
\text { Üniversitesi: } \\
2 \\
\text { Devlet } \\
\text { Üniversitesi: } \\
10 \\
\text { Toplam: } 12\end{array}$ & $\begin{array}{l}\text { Düz Lise: } \\
3 \text { Meslek } \\
\text { Lisesi: } 6 \\
\text { Çok } \\
\text { Programlı } \\
\text { Lise: } 2 \\
\text { Anadolu } \\
\text { Lisesi: } 1 \\
\text { Toplam: } 12\end{array}$ & $\begin{array}{l}\text { 0-4 y1l: } 2 \\
\text { 10-14 y1l: } 4 \\
\text { 15-19 y1l: } 4 \\
\text { 20-24 y1l: } 1 \\
\text { 25-29 y1l: } 1 \\
\text { Toplam: } 12\end{array}$ \\
\hline
\end{tabular}

Tablo 1 incelendiğinde araştırma grubunu oluşturan öğretmenlerin 11'i kadın, 1'i erkektir. 2 kişi 20-24 yaş, 3 kişi 30-34 yaş, 4 kişi 35-39 yaş, 1 kişi 40-44 yaş, 2 kişi 45-49 yaş aralığındadır. Öğretmenlerin öğrenim düzeyleri, 1 kişi ön lisans, 10 kişi lisans (2 öğretmen lisansüstü eğitimine devam etmektedir), 1 kişi lisansüstü eğitimini tamamlamıştır. Eğitim alınan üniversite türleri; 2 öğretmen vakıf üniversitesinden, 10 öğretmen devlet üniversitesinden mezun olmuştur. Mezun olunan lise türü ise 1 kişi Anadolu Lisesi, 6 kişi meslek lisesi, 2 kişi çok programlı lise ve 3 kişi düz lise eğitimi almıştır. Meslekteki hizmet süresi; 2 kişi 0-4 yıl, 4 kişi 10-14 yıl, 4 kişi 15-19 yıl, 1 kişi 20-24 yıl, 1 kişi 25-29 yıl aralığında değişmektedir. Araştırmaya katılan bütün öğretmenler okul öncesi eğitimi bölümünü isteyerek seçtiklerini belirtmişlerdir.

\section{Veri Toplama Araçları}

Araştırmada; yarı yapılandırılmış görüşme formu kullanılarak veriler toplanmıştır. Araştırmada öğretmenlere, dört ana tema altında, araştırmacı tarafından hazırlanan toplam 8 adet açık uçlu soru sorulmuştur. 5 alan uzmanının görüşüne başvurulmuştur. Gelen geri bildirimlere göre form yeniden düzenlenmiştir. Ana temalar ve ilgili sorular aşağıda belirtilmiştir.

Araştırmada ele alınan dört ana tema iç içe geçmiş süreçlerden oluşmaktadır. Ana temalar şu şekildedir; 
- Planlama Süreci

- Okul Yönetiminin Tutumu

- Değerlendirme

- Programların kiyaslanması

“Planlama Süreci” konulu temayı incelemek amacıyla öğretmenlere dört görüşme sorusu yöneltilmiştir:

Plan (aylık, günlük) yazarken ne kadar zaman harcıyorsunuz/ ayırıyorsunuz?

1. Plan yazarken yararlandığınız kaynaklar var mı? Varsa hangileridir?

2. Günlük planlarınızı hangi sıklıkla yazarsınız?

3. Plan yazarken nelere dikkat ediyorsunuz? Zorlandığınız noktalar var mıdır?

Varsa nelerdir?

“Okul Yönetiminin Tutumu” konulu temayı incelemek amaciyla öğretmenlere iki görüşme sorusu yöneltilmiştir:

1. Okul yönetiminin size sınıfta kullanmanız için yönlendirdiği etkinlik kitapları ve planları oluyor mu? Olduysa içeriği ve uygulaması hakkında ne düşünüyorsunuz?

2. Okul yönetiminin kullanacağınız etkinlik kitapları ve planları hususunda yaklaşımını nasıl değerlendirirsiniz?

3. Plan yazmaya vaktiniz kalmadığında nasıl bir çözüm yolu buluyorsunuz? Hangi sebeplerden dolayı plan yazmaya vaktiniz kalmıyor ya da yazamıyorsunuz?

4. 2013 Okul Öncesi Eğitim Programıyla alakalı hizmet içi eğitim ya da program dersi aldınız mi?

"Değerlendirme" konulu temayı incelemek amaciyla öğretmenlere bir görüşme sorusu yöneltilmiştir:

1. Aylık ve günlük planlarınızın değerlendirmesini hangi sıklıkla yaparsınız?

Değerlendirmelerinizde ölçüt aldığınız durumlar nelerdir?

"Programların Kıyaslanması" konulu temayı incelemek amacıyla öğretmenlere bir görüşme sorusu yöneltilmiştir:

1. Diğer okul öncesi eğitimi programlarıyla kıyasladığınızda hangi MEB programının daha nitelikli olduğunu düşünüyorsunuz? Nedenleri nelerdir? 


\section{Verilerin Toplanması}

Görüşmeler, öğretmenlerin gönüllülük esasına dayanılarak yapılmıştır. Araştırmanın uygulanma sürecinde öğretmenlere görüşmenin amacı kısaca anlatılmış, öğretmenlerin adı-soyadı gibi kişisel bilgilerinin istenmediği ve kimlik bilgilerinin hiçbir yerde geçmeyeceği, bu görüşmelerin gizli kalacağı, soruları cevaplarken gerçek düşüncelerini söylemekten çekinmemeleri gerektiği uygun bir şekilde açıklanmıştır.

Öğretmenlerlegörüşmeyegeçilmedenöncekısabirtanışmasohbetigerçekleştirilmiştir. Tarafsız olmaya çalışılarak yönlendirme yapılmamıştır. Araştırmacının, sürecin doğal bir üyesi haline gelmesi amaçlanmıştır.

Görüşmeler sınıf içerisinde ya da anasınıflarının görüşmeye müsait bir odasında yapılıp; mesai bitiminde ya da mesai başlamadan önce, güne başlama zamanında (bu yorumu dikkate almayalım derim), oyun saatinde ve etkinlik geçişlerinde gerçekleştirilmiştir.

\section{Verilerin Analizi}

Verilerin analizinde Strauss ve Corbin'in (1990) de önerdiği betimsel analiz yaklaşımı (akt. Yıldırım ve Şimşek, 2013) uygulanmıştır. Betimsel analizde elde edilen veriler düzenlenir, önceden belirlenen temalara göre özetlenir ve yorumlanır. Bulgular arasında neden- sonuç ilişkisi kurulur veya karşılaştırmalar yapılır (Karataş, 2015). Betimsel analizin dört aşaması (Yıldırım ve Şimşek, 2013) uygulanmıştır:

1. Betimsel Analiz İçin Bir Çerçeve Oluşturma: Araştırma sorularından ve görüşmede bulunan boyutlardan yola çıkılarak veri analizi için bir çerçeve oluşturulmuştur. Bu çerçeveye göre verilerin hangi temalar altında sunulacağı belirlenmiştir.

2. Tematik Çerçeveye Göre Verilerin İşlenmesi: Daha önce oluşturulan çerçeveye göre elde edilen veriler okunup düzenlenmiştir. Bu aşamada, daha sonra sonuçlar yazılırken kullanılacak doğrudan alıntılar da seçilmiştir.

3. Bulguların Tanımlanması: Düzenlenen veriler tanımlanmış ve gerekli yerlerde doğrudan alıntılarla desteklenmiştir.

4. Bulguların Yorumlanması:Tanımlanan bulgularınaçıklanması, ilişkilendirilmesi ve anlamlandırılması yapılmıştır.

\section{Geçerlik - Güvenilirlik Çalışması}

Nitel araştırmada "geçerlik" bilimsel bulguların doğruluğu, "güvenirlik" ise bilimsel bulguların tekrarlanabilirliği ile ilgilidir (Yıldırım ve Şimşek, 2013). Araştırmanın geçerliği ve güvenirliği artırmak için aşağıdaki çalışmalar gerçekleştirilmiştir; 
a. Araştırmanın inandırıcılığı (iç geçerliği): İlgili alanyazın taranmış ve temalar belirlenerek görüşme formu hazırlanmıştır. Temalar ile sorular arasındaki anlam bütünlüğü sağlanmış ve sorular beş uzmana kontrol ettirilerek son hali verilmiştir. Görüşmeler için sırayla okul yöneticilerinden gerekli izinler alınmış, öğretmenlerle kısa bir ön görüşme yapılmış ve araştırma içeriği anlatılmıştır. Böylelikle karşılıklı güven ilişkisi sağlanarak; öğretmenlere isimlerinin ve okullarının araştırmada belirtilmeyeceği söylenmiş, dolayısıyla soruları cevaplandırırken samimiyetle ve endişeden uzak bir şekilde görüşme yapılması sağlanmıştır. Böylece verilerin mümkün olduğunca gerçeği yansıtmasına önem verilmiştir.

b. Araştırmanın aktarılabiliriliği (dış geçerliği): Yöntem bölümünde, araştırmanın modeli, çalışma grubu, veri toplama aracı, veri toplama süreci, verilerin analizi ve verilerin yorumlanması ayrıntılı bir biçimde anlatılmıştır.

c. Araştırmanın tutarlığı (iç güvenirliği): Bulguların önce yorumsuz sunumu, görüşmelerin alanyazındaki bilgilerle onaylanması ve önceden oluşturulmuş ayrıntılı kavramsal çerçeveye bağlı veri analizi ile yapılmıştır.

d. Araştırmanın teyit edilebilirliği (dış güvenirliğini): Veri toplanan bireylerin, verilerin analizinde kullanılan kavramsal çerçeve, varsayımlar, veri toplama ve analiz yöntemlerinin tanımlanması ile sağlanmıştır. Araştırmacılar, süreçte yapılanları ayrıntılı bir biçimde tanımlamıştır. Bununla birlikte elde edilen ham veriler ve kodlamalar başkaları tarafından incelenebilecek şekilde araştırmacı tarafindan saklanmaktadır.

Ayrıca, çalışmanın güvenirliği için Miles ve Huberman'dan (2016) yararlanılmıştır. Okul öncesi eğitimde uzman olan iki araştırmacının arasında ki görüş birliğini belirlemek için: Uyuşum Yüzdesi= [Görüş birliği/görüş ayrılığ1 + Görüş birliği]*100 formülü uygulanmıştır. $\mathrm{Bu}$ çalışmada uyuşum yüzdesi \% 80 olarak belirlenmiştir. İnceleme sonrasında araştırmacılar arasında görüş birliğine vararak verileri düzenlemişlerdir.

\section{Bulgular}

Araştırmada ele alınan dört temanın kapsamını 2013 Okul Öncesi Eğitim Programında bulunan eğitim planlarının öğretmenler tarafından değerlendirilmesi oluşturmaktadır. $\mathrm{Bu}$ ana temalar 1şığında ortaya çıkan bulgular aşağıda sunulmuştur.

\section{1. "Planlama Süreci" Temasına İlişkin Bulgular}

Tablo 2'de yer alan "Aylık plan yazarken ne kadar zaman harcıyorsunuz/ ayırıyorsunuz?” sorusuna öğretmenlerin neredeyse yarısına yakını (Ö.2, Ö.3, Ö.7, Ö.9, Ö.10) "hazır plan kullanıyorum" şeklinde mevcut durumlarını ifade etmişlerdir. Ayrıca 
Ö.10 hazır plan kullandığını şu şekilde ifade etmiştir, "Plan yazmıyorum. Programın işleği doğrultusunda set aldık, içinde planda var”. Bu sonucun yanında, katılımcılardan Ö.1'in, aylık plan hazırlama süresinin "1 hafta" sürdüğünü belirtmesi öğretmenlerin aylık planlara gösterdikleri hassasiyetle farklılık göstermektedir.

Tablo 2

Ögretmenlerin “aylık plan yazarken ne kadar zaman harcıyorsunuz/ayırıyorsunuz?" sorusuna verdikleri cevaplar

\begin{tabular}{lc}
\hline \multicolumn{1}{c}{ Cevaplar } & $\mathrm{f}$ \\
\hline Hazır plan kullanıyorum & 5 \\
$1-1,5$ saat & 3 \\
Sene başında toplu yapılıyor & 3 \\
1 hafta & 1 \\
\hline
\end{tabular}

Tablo 3

Öğretmenlerin "günlük plan yazarken ne kadar zaman harcıyorsunuz/ayırıyorsunuz?" sorusuna verdikleri cevaplar

\begin{tabular}{ll}
\hline \multicolumn{1}{c}{ Cevaplar } & $\mathrm{f}$ \\
\hline Hazır plan kullanıyorum & 5 \\
15- 30 dakika & 4 \\
Sene başında toplu yapılıyor & 2 \\
Toplu yapılıyor & 1 \\
\hline
\end{tabular}

Tablo 3'de görüldüğü üzere "Günlük plan yazarken ne kadar zaman harclyorsunuz/ ayırıyorsunuz?" sorusuna katılımcılar "hazır plan kullanıyorum (Ö.2, Ö.3, Ö.7, Ö.9, Ö.10), 15-30 dakika, 1- 1,5 saat" şeklinde cevaplamışlardır. Tablo 2'de görülen hazır plan kullanma sayısı değişmemiş olup öğretmenlerin cevaplarında tutarlılık gözlenmiştir.

Tablo 4'ü incelediğimizde “Günlük planlarınızı hangi sıklıkla yazarsınız?” sorusuna verilen cevaplar "Hazır plan kullanıyorum (Ö.1, Ö.2, Ö.5, Ö.7), her gün, sene başında toplu yazıyorum" şeklinde çeşitlilik göstermiştir. "Belirli bir rutinim yok" şeklinde cevaplayan Ö.10, araştırmacıların zihninde eğitim planı yazmak için belirli bir çalışma alışkanlığı veya rutinine sahip olmadıklarını şeklinde yorumlanabilir.

Tablo 2, 3 ve 4 incelendiğinde öğretmenlerin her sene değişen öğrencilere göre yeni plan yapmaları gerekirken neredeyse yarısı "Hazır plan kullanıyorum" ifadesi, yeni sınıfın gelişimsel ihtiyaçlarına göre plan yapmayı tercih etmediklerini düşündürmektedir. 
Tablo 4

Öğretmenlerin “günlük planlarınızı hangi sıklıkla yazarsınız?” sorusuna verdikleri cevaplar

\begin{tabular}{ll}
\hline \multicolumn{1}{c}{ Cevaplar } & $\mathrm{f}$ \\
\hline Hazır plan kullanıyorum & 4 \\
Her gün & 3 \\
Sene başında toplu yazıyorum & 2 \\
2 günde bir & 1 \\
Haftada bir & 1 \\
Belirli bir rutinim yok & 1 \\
\hline
\end{tabular}

Tablo 5

Öğretmenlerin “plan yazarken yararlandı̆̆ınız kaynaklar var mı? varsa hangileridir?" sorusuna verdikleri cevaplar

\begin{tabular}{ll}
\hline \multicolumn{1}{c}{ Cevaplar } & $\mathrm{f}$ \\
\hline İnternet & 6 \\
Kitap & 4 \\
Eski tecrübelerimden & 3 \\
Üniversite hocalarından & 2 \\
MEB programından & 2 \\
Hazır plan kullanıyorum & 2 \\
Dergi & 1 \\
Meslektaşlarımdan & 1 \\
Yabancı kaynaklardan & 1 \\
Yararlandığım kaynak yok & 1 \\
\hline
\end{tabular}

Tablo 5, 4, 3 ve 2 incelendiğinde hazır planla ilgili verilen cevaplar arasında tutarlılık saptanmamıştır. Tablo 5'de "Plan yazarken yararlandığınız kaynaklar var mı? Varsa hangileridir?" sorusuna 2 öğretmen (Ö.2 ve Ö.5) "hazır plan” cevabını verirken; Tablo 2 ve 3'de "hazır plan kullanıyorum" cevabını 5 kişi vermiştir. Bu durum Tablo 2 ve 3'e göre 3 öğretmenin aylık ve günlük plan yazmayıp, hazır plan kullandıklarını gösterse de Tablo 5'e göre çeşitli kaynaklardan etkinlik araştırıp uygulamaktadırlar. Bu durum, hazır plan kullanan öğretmenlerin yarısından fazlasının iki planla çalıştığını işaret etmektedir. 
Birinci planın resmi evrak olarak gösterildiği; ikinci planın ise yazıya geçirilmemiş ama öğretmenin sınıfta uyguladığı asıl etkinliklerden oluştuğunu düşündürmektedir.

Tablo 6 incelendiğinde "Plan yazarken nelere dikkat ediyorsunuz?" sorusuna öğretmenler aynı cevapları vermemişlerdir. Bu yüzden verilen cevaplar ayrı ayrı yazılmıştır. Yalnız 5 kişi "Yaş grubuna", 2 kişi "Materyal yönünden ulaşıma”, 2 kişi "Okulun fiziksel şartlarına" diyerek ortak cevap verilmiştir.

Tablo 6

Öğretmenlerin "plan yazarken nelere dikkat ediyorsunuz?" sorusuna verdikleri cevaplar

\section{Cevaplar}

Yaş grubunun ihtiyacına

Uzun zamandır plan yazmıyorum, hazır plan

kullaniyoruz

Planın tamamını yazmak zor geliyor, not alarak

çalışıyorum

Uyarlama kısmında zorlanıyorum

Yaş grubuna ve gelişimlerine, velilerin profiline,

okulun fiziksel ve çevresel şartlarına

Yaş grubuna, materyal yönünden ulaşıma, okulun

fiziksel şartlarına, uygulamanın yoruculuğuna,

sınıfta problemli öğrenci olup olmadığına ve hazırlık

sürecinin ne kadar süreceğine

Çocuklara uygunluğuna ve dikkat çekici olmasına

Yaş grubuna, çocukların eğitim seviyelerine ve faklı

şekilde öğrenenlere hitap etmeye çalışıyorum

Eğitimsel ihtiyaçlarına dikkat ediyorum

Kazanım -göstergelerin azlığına ve kazanım-

göstergelerin etkinliğe uyumuna

Çocuk açısından uygulanabilir olmasına, belirli gün

ve haftalara ve değerler eğitimine

Yaş gruplarına, öğrencilerin hazır bulunuşluk

düzeyine, bireysel farklılıklara ve elimdeki

materyale uygun

Tablo 7'de görüldüğü üzere "Plan yazarken zorlandığınız noktalar var mıdır? Varsa nelerdir?" sorusuna öğretmenler "Zorlandığım nokta yok, fiziksel ortamın uygun olmaması, malzemelerin uygun olmaması, hazır plan kullanıyorum, planın tamamını yazmak zor geliyor, uyarlama kısmında, süre planlanmasında, merkezleri oluşturmada, çocukları ve ortamı görmeden toplu plan yazmak, hangi ayda hangi kazanımgöstergelerin kullanılacağının belirlenmesi” şeklinde cevaplamışlardır. 
"Plan yazarken zorlandığınız noktalar var mıdır? Varsa nelerdir?" sorusuna çok sayıda "Hazır plan kullanıyorum" cevabı alınmıştır. Bunun üzerine soru şu şekilde tekrar edilmiştir "Plan yazarken zorlandığınız için mi hazır plan kullanıyorsunuz? Sizi plan yazarken zorlayan noktalar neydi ki hazır plana yönlendiniz?”. Öğretmenler bunun üzerine Tablo 7'de görülen cevapları yazmışlardır ve en dikkat çekici cevaplar ise Ö.2’nin “Uzun zamandır plan yazmıyorum, hazır kullanıyoruz.” şeklinde verilen cevapla, Ö.3’ün "Planın tamamını yazmak zor geliyor” cümlesi olmuştur.

Tablo 7

Öğretmenlerin "plan yazarken zorlandığınız noktalar var mıdır? varsa nelerdir?" sorusuna verdikleri cevaplar

\begin{tabular}{lc}
\hline \multicolumn{1}{c}{ Cevaplar } & $\mathrm{f}$ \\
\hline Zorlandı̆̆ım nokta yok & 3 \\
Fiziksel ortamın uygun olmaması & 2 \\
Malzemelerin uygun olmaması & 2 \\
Sınıftaki çocukların yaş gruplarının farklı & 1 \\
olması & 1 \\
Hazır plan kullanıyorum & 1 \\
Planın tamamını yazmak zor geliyor & 1 \\
Uyarlama kısmında & 1 \\
Süre planlanmasında & 1 \\
Merkezleri oluşturmada & 1 \\
Çocukları ve ortamı görmeden toplu plan & 1 \\
yazmak & 1 \\
Hangi ayda hangi kazanım- göstergelerin & \\
kullanılacağının belirlenmesi & \\
\hline
\end{tabular}

Öğretmenler uygulamanın içine girince çocuklarla çalışmanın getirdiği fiziksel ve zihinsel yorgunluktan ötürü etkinlikleri sistematik bir şekilde yazarak kâğıda dökmeyi yorucu bir meşguliyet olarak algılayabilmektedirler. Hâlbuki her ay düzenli olarak, çalışılan sınıfın yaş ve gelişim özelliklerine göre plana alınacak kazanım ve göstergelerin düzenlenmesi çocukların bütüncül gelişimleri açısından kritik bir önem taşımaktadır. 2013 Okul Öncesi Eğitim Programının tüm gelişim alanlarına yönelik (Bilişsel, Sosyal-Duygusal, Dil, Motor gelişimleri ve öz bakım becerileriyle ilgili) aylık planda yer alan göre kazanım-göstergelerin hangileri için yer verildiği durumuyla ilgili çizelgesi bulunmaktadır (MEB, 2013)

Öğretmenler, hazır plan uygulasalar da, hazır plandan kısmen yararlanıp yeni plan yazsalar da veya başka kaynaklardan yararlansalar da oluşturdukları plana göre 
öğrencilerinin gelişimlerini kazanım gösterge çizelgesine işlemesi gerekmektedir. Böyle yapılması çocukların temel eğitime ve hayata hazırlanmasında bir izlence görevi gösterecektir. Bu izlenceler, ailelerle yapılan görüşmeler sırasında ailenin çocuğunun gelişimi için yapabileceklerini ortaya çıkarmak adına bir mevcut durum belgesi fonksiyonu yerine geçecektir.

\section{2. “Okul Yönetiminin Tutumu” Temasına İlişkin Bulgular ve Sonuçlar}

Tablo 8

Öğretmenlerin "Okul yönetiminin size sinıfta kullanmanı için yönlendirdiği etkinlik kitapları ve planları oluyor mu?” Sorusuna Verdikleri Cevaplar

Cevaplar f

Olmuyor 10

Oluyor 2

Tablo 8 incelendiğinde "Okul yönetiminin size sınıfta kullanmanız için yönlendirdiği etkinlik kitapları ve planları oluyor mu?" sorusuna 10 öğretmen "Olmuyor" şeklinde cevaplamışlardır.

Tablo 9

Öğretmenlerin "okul yönetiminin size sınıfta kullanmanız için yönlendirdiği etkinlik kitapları ve planları olduysa içeriği ve uygulaması hakkında ne düşünüyorsunuz?” sorusuna verdikleri cevaplar

\begin{tabular}{ll}
\hline \multicolumn{1}{c}{ Cevaplar } & $\mathrm{f}$ \\
\hline Burası sonsuz kaynak veriyor & 1 \\
Bizim tercihlerimiz doğrultusunda yeterli oluyor & 1 \\
MEB'in Pamuk Şekeri kitabını kullanıyoruz & 1 \\
\hline
\end{tabular}

Tablo 9 incelendiğinde ise Tablo 8'de “Oluyor" cevabını veren 2 öğretmen ve "Olmuyor" cevabını veren Ö.8 "Okul yönetiminin size sınıfta kullanmanız için yönlendirdiği etkinlik kitapları ve planları olduysa içeriği ve uygulaması hakkında ne düşünüyorsunuz?" sorusunu cevaplamışlardır. Verilen cevaplar "Burası sonsuz kaynak veriyor, bizim tercihlerimiz doğrultusunda yeterli oluyor, MEB'in Pamuk Şekeri kitabını kullanıyoruz" şeklinde olmuştur. Tablo 8'de "Okul yönetiminin size sınıfta kullanmanız için yönlendirdiği etkinlik kitapları ve planları oluyor mu?" sorusuna "Olmuyor" 
cevabını veren Ö.8, Tablo 9'un sorusunu “Burası sonsuz kaynak veriyor” şeklinde cevaplamıştır. Hâlbuki okul yönetimin sağladığı imkânlar sorulmamıştır, öğretmenin burada soruyu yanlış anladığı düşünülmektedir. Ö.10'un “Bizim tercihlerimiz doğrultusunda yeterli oluyor” şeklinde verdiği cevapsa aslında okul yönetiminin sınıfta uygulanması için bir etkinlik kitabı veya planı olmadığını, öğretmenin tercihine bırakıldığını işaret etmektedir. Ayrıca aynı okuldan başka bir öğretmen olan Ö.9 "Yok, yönlendirme yapmıyor. Biz kendimiz seçiyoruz." şeklinde cevap vermesi okul yönetiminin böyle bir yönlendirme yapmadı̆̆ını göstermektedir. Ö.12'nin “MEB'in Pamuk Şekeri kitabını kullanıyoruz" şeklinde verdiği cevabın devamındaysa "Set e kullanıyoruz." demiştir. Ayrıca aynı okulda başka bir öğretmen olan Ö.11 bu soruya "Okul yönetimi yönlendirmiyor. Genelde biz yönlendiriyoruz. Kaynak olarak kitap kullanıyoruz." şeklinde cevap vermesi aynı okulda çalışan öğretmenler arasındaki uygulama farklılıklarını ortaya koymaktadır.

Tablo 8 ve 9 incelendiğinde verilen tüm cevaplarda tutarsızlık görülmektedir ve okul yönetiminin öğretmenlere sınıfta kullanmaları için yönlendirdiği etkinlik kitapları ve planların olmadığı, öğretmenlerin kendi istekleri doğrultusunda tercih yaptıkları görülmüştür.

Tablo 10 incelendiğinde "Okul yönetiminin kullanacağınız etkinlik kitapları ve planları hususunda yaklaşımını nasıl değerlendirirsiniz?” sorusunu bütün öğretmenler (12 kişi) cevaplamışlardır. Verilen cevapların bazıları şu şekildedir; "Bizim fikirlerimize önem veriyor, öğretmeni özgür bırakıyor, zümre kararına bırakıyorlar”. Bu cevaplar ve öğretmenlerin görüşme sırasında ki vücut dilleri göz önüne alınırsa okul yönetiminin sınıf yönetimine karışmaması öğretmenler açısından olumlu karşılanmaktadır. Bunların yanı sıra dikkat çeken başka bir durum Ö.1'in şu şekilde cevaplamasıdır; "Okul müdürü okul öncesi mezunu olmadığı için bu konuları anlamıyor ve bilmiyor, sürekli bize soruyor, müfettiş baktığı için yazılıyor zaten”. Bu cevaplardan hareketle, okul yönetiminin okul öncesi eğitim alanında uzmanlığa sahip olmaması, yönetim ile öğretmenler arasında ortak bir dilin gelişmesine engel teşkil edebileceği söylenebilir. Ayrıca, okul öncesi eğitim planlarının hazırlanmasında okul yöneticilerinin de sorumluluklarının olduğu göz önünde bulundurulduğunda alan uzmanı olmalarının önemi ortaya çıkmaktadır. 
Tablo 10

Öğretmenlerin "okul yönetiminin kullanacă̆ını etkinlik kitapları ve planları hususunda yaklaşımını nasıl değerlendirirsiniz?” sorusuna verdikleri cevaplar

\begin{tabular}{|c|c|}
\hline Cevaplar & $\mathrm{f}$ \\
\hline Bizim fikirlerimize önem veriyor & 4 \\
\hline Öğretmeni özgür bırakıyor & 3 \\
\hline Olumludur & 3 \\
\hline Zümre kararına bırakıyorlar & 2 \\
\hline $\begin{array}{l}\text { Okul müdürü okul öncesi mezunu olmadığı için bu } \\
\text { konuları anlamıyor ve bilmiyor, sürekli bize soruyor }\end{array}$ & 1 \\
\hline Okulun getirisine bakmıyor & 1 \\
\hline Çocuğa ve programa uygun olmasını istiyorlar & 1 \\
\hline Güncellenmiş olmasını istiyorlar & 1 \\
\hline Müfettiş baktığı için yazılıyor zaten & 1 \\
\hline Düzenli yapılmasını istiyor & 1 \\
\hline Etkinlik kitabı kullanıp kullanmamayı bize bırakıyor & 1 \\
\hline MEB'e göre yönlendiriyor & 1 \\
\hline Devletin gönderdiği kitapları kullanıyoruz & 1 \\
\hline Destekleyiciler & 1 \\
\hline Karışmiyorlar & 1 \\
\hline Yeterli buluyorum & 1 \\
\hline Kasmiyor & 1 \\
\hline Sıkıntımız olursa hemen çözüyor & 1 \\
\hline Sınıf içine müdahale etmiyor & 1 \\
\hline
\end{tabular}

Tablo 11'i incelediğimizde "Plan yazmaya vaktiniz kalmadığında nasıl bir çözüm yolu buluyorsunuz?” sorusuna öğretmenler “Hazır plan kullanıyorum (Ö.2, Ö.7, Ö.8), planı sene başında toplu yazdığımız için sorun olmuyor, tecrübelerimden yararlanıyorum" şeklinde cevaplamışlardır. Tablo 2 ve 3 incelendiğinde "Hazır plan kullanıyorum" 
cevabını veren 5 öğretmen varken, Tablo 11'de hazır plan kullandığını söyleyen öğretmen sayısı 3 kişiye inmiştir. Bu durum Tablo 5'de gözlendiği gibi hazır plan kullanan öğretmenlerin yarısından fazlasının iki planla çalıştığını düşündürmektedir. Birinci plan resmi evrak olarak gösterilirken; ikinci plan ise yazıya geçirilmemiş ama öğretmenin uyguladığı etkinliklerden oluştuğuna işaret etmektedir. 2013 Okul Öncesi Eğitim Programının temel özelliklerinden biri esnek olmasıdır (MEB, 2013). Bu özelliğe göre, öğretmenler hazır planlardan yararlanıp sınıfın yapısına, çocukların yaş ve gelişim özelliklerine göre yeniden düzenleyebilirler. Hatta planın değerlendirme kısmında revize ettikleri bölümleri yazma imkânı tanınmaktadır. Fakat çalışma grubundaki öğretmenler bunu da yapmayıp iki planla çalıştıkları üzerine tahminler artmaktadır.

Tablo 11

Öğretmenlerin "plan yazmaya vaktiniz kalmadı̆̆ında nasıl bir çözüm yolu buluyorsunuz?" sorusuna verdikleri cevaplar

\begin{tabular}{ll}
\hline \multicolumn{1}{c}{ Cevaplar } & $\mathrm{f}$ \\
\hline Hazır plan kullanıyorum & 3 \\
$\begin{array}{l}\text { Planı sene başında toplu yazdığımız için sorun } \\
\text { olmuyor }\end{array}$ & 2 \\
Tecrübelerimden yararlanıyorum & 2 \\
Plan yazmak benim için çok sıkıntı değil & 1 \\
1 günlük planı 2 günde uyguluyorum & 1 \\
Daha önce öğrettiklerimi tekrar ediyorum & 1 \\
Sinıftaki materyalleri kullanıyorum & 1 \\
Kaynak plan kullanıyorum & 1 \\
\hline
\end{tabular}

Ayrıca Tablo 11 incelendiğinde Ö.4'ün "Planı sene başında toplu yazdığımız için sorun olmuyor" cevabı 2013 Okul Öncesi Eğitim programında yer alan aylık eğitim planı anlayışına taban tabana bir zıtlık oluşturmaktadır. Öğretmenin vereceği eğitim aylık dönemler hâlinde planlaması önerilmektedir. Aylık plan, bir öğretmenin çalıştığı çocuk grubunun gelişimini desteklemek için etkinlik oluşturmak üzere alacağı kazanım ve göstergeleri, kavramları, alan gezilerini, özel gün ve haftalar ile aile katılımı ve değerlendirme süreçlerini içeren bir çalışma planıdır (MEB, 2013). Ayrıca bu durum çocukların bütüncül gelişimleri açısından önem arz etmektedir. Öğretmenin o ay için alması gereken kazanımları, ilgili göstergeleri ve kavramları belirleyebilmesi için, çocukları rutin olarak gözlemlemesi ve gözlemlediği gelişim özelliklerini "Gelişim Gözlem Formu"na kaydetmesi gerekmektedir. Gözlemlerden elde edilen bilgiler doğrultusunda çocukların desteklenmesi gereken gelişim özelliklerinin dikkate alınması önemsenmelidir (MEB, 2013). Tablo 11'e baktığımızda "1 günlük planı 2 günde uyguluyorum" dikkat çeken bir başka cevaptır. Bu durum 2 haftada toplam 10 günlük eğitim planı yazılması gerekirken 5 tane yazıldığını başka bir ifadeyle plan yazmakla uğraşılmadığını düşündürmektedir.

Tablo 12 
Öğretmenlerin "hangi sebeplerden dolay plan yazmaya vaktiniz kalmıyor ya da yazamiyorsunuz?" sorusuna verdikleri cevaplar

\begin{tabular}{lc}
\hline \multicolumn{1}{c}{ Cevaplar } & $\mathrm{f}$ \\
\hline Okulda ekstra ders dışı çalışma olursa & 1 \\
Aile yaşantısından dolayı & 1 \\
Her gün günlük plan yazmak yorucu & 1 \\
Özel gün çok fazla & 1 \\
Okulun beklentisi var & 1 \\
Velinin beklentisi var & 1 \\
Çocuğun beklentisi var & 1 \\
Yoğun yaşadığım günlerde & 1 \\
Vakit sıkıntısı yaşıyorum & 1 \\
Hiç sıkıntı yaşamıyorum & 1 \\
\hline
\end{tabular}

Tablo 12' de yer alan "Hangi sebeplerden dolayı plan yazmaya vaktiniz kalmıyor ya da yazamıyorsunuz?" sorusuna "Okulda ekstra ders dişı çalışma olursa, aile yaşantısından dolayı, her gün günlük plan yazmak yorucu, okulun beklentisi var, velinin beklentisi var, çocuğun beklentisi var, hiç sıkıntı yaşamıyorum” şeklinde cevaplar gelmiştir. En dikkat çeken cevap ise Ö.11'in "Her gün günlük plan yazmak yorucu” şeklinde verdiği cevaptır. Tablo 5 'in cevaplarına baktığımız zaman öğretmenlerin etkinlik oluşturmak için çok çeşitli kaynaklardan yararlandığı görülmektedir ve bu durum aslında öğretmenlerin kişisel olarak eğitime verdikleri önemi gösterirken her gün günlük plan yazmak yorucu olduğu için çift plan kullandıklarını düşündürmektedir.

Tablo 13'de görüldüğü üzere "2013 Okul Öncesi Eğitim Programıla alakalı hizmet içi eğitim ya da program dersi aldınız mı?" sorusuna 9 öğretmen "Hizmet içi eğitim aldım”, 1 öğretmen "Hizmet içi eğitim almadım”" şeklinde cevaplamışlardır. Hizmet içi eğitim almayan öğretmen Ö.3’ün meslekteki hizmet süresi 20 yıldır. "Neden hizmet içi eğitim almadınız?" sorusu sorulduğunda ise verdiği cevap "Eğitim veren kişilerin çok vasat olduğunu düşünüyorum. Kendileri uygulama yapmadan bize eğitim veriyorlar." şeklinde olmuştur. Yine meslekteki hizmet süresi 27 yıl olup "Hizmet içi eğitim aldım" şeklinde cevap veren bir başka katılımcı Ö.8 ise "Konuşmacıya bağlı olarak bazıları çok iyi, bazıları çok gereksizdir. Bazı eğitimler bana tekrar oluyor ve sıkılıyorum. Yine de hepsinin bir yararını görüyoruz." şeklinde cevabına bir ilave yapmıştır. Meslekteki hizmet süresi uzun olan öğretmenlerin düşüncelerine göre hizmet içi eğitim veren konuşmacıların daha gerçekçi olmalarını ve öğretmenlerin ciddi anlamda sorun yaşadıkları alanlar göz önüne alınarak eğitim verilmesi gerekliliğini göstermektedir. 
Tablo 13

Öğretmenlerin "2013 Okul Öncesi Eğitim Programıla alakalı hizmet içi eğitim ya da program dersi aldınız mı?” sorusuna verdikleri cevaplar

Cevaplar

Hizmet içi eğitim aldım

Hizmet içi eğitim almadım

Program dersi aldım

\section{3.“Değerlendirme” Temasına İlişskin Bulgular ve Sonuçlar}

Tablo 14 incelendiğinde "Aylık ve günlük planlarınızın değerlendirmesini hangi sıklıkla yaparsınız?” sorusuna öğretmenlerden bazıları "Ben olması gerektiği gibi söyleyeyim.” diyerek, "Aylık planları aylık yaparım, günlük planları günlük yaparım, günlük planları haftalık değerlendiririm” şeklinde cevap vermişlerdir. Eğitimin bütün aşamalarında, gerçekleştirilen eğitim ve öğretim etkinliklerinin ne derece etkili olduğunun belirlenmesi son derece önemlidir. Araştırma bulguları, eğitim aşamalarının birbirine bağlı olduğunu; üst aşamadaki öğrenmeleri bir önceki aşamada yeterli düzeyde gerçekleşen öğrenmelerin olumlu, gerçekleşmeyen öğrenmelerin ise olumsuz etkilediğini göstermektedir. $\mathrm{Bu}$ anlamda okul öncesi dönem, çocuklar için gerekli olan temel yaşam becerilerinin ve üst eğitim aşamaları için gerekli olan temel bilgi ve becerilerin kazanılması gereken önemli bir eğitim dönemidir. Bu yaşlarda verilecek eğitim, çocukların bilişsel, dil, motor, sosyal ve duygusal gelişim alanları ile öz bakım becerilerinin eş güdümlü ve çok boyutlu olarak desteklenmesini ve çocukların bireysel özelliklerini dikkate alarak nesnel olarak değerlendirilmesini zorunlu kılar (MEB, 2013). $\mathrm{Bu}$ duruma göre değerlendirmenin önemi ortaya çıkarken Tablo 6 incelendiğinde "Plan yazarken nelere dikkat ediyorsunuz?" sorusuna sadece 1 öğretmen (Ö.5) çocukların gelişimlerine dikkat ediyorum demiştir. Hâlbuki değerlendirmenin amacı, eğitim planı oluştururken çocukların gelişimsel ihtiyaçlarına göre öğretmene yardım etmektir. Fakat elde edilen verilere göre öğretmenlerin çoğu değerlendirme yapsalar da amacına uygun yapmamaktadırlar ya da öğretmenler değerlendirme kısımlarını sadece günlük planda bu kısmının dolu gözükmesi için standart cümleler yazıp, çocukları kendi yöntemleriyle değerlendirmektedirler. Ancak, kendilerine özgü bu değerlendirme yöntemleriyle ilgili sistemli bir çalışma yaptıklarına dair açıklamalar yapmamışlardır. 
Tablo 14

Öğretmenlerin "aylık ve günlük planlarınızın değerlendirmesini hangi sıklıkla yaparsinız?” sorusuna verdikleri cevaplar

\begin{tabular}{ll}
\hline \multicolumn{1}{c}{ Cevaplar } & $\mathrm{f}$ \\
\hline Aylık planları aylık yaparım & 8 \\
Günlük planları günlük yaparım & 6 \\
Günlük planları haftalık değerlendiririm & 3 \\
Günlük planları anında, ders saatinde & 1 \\
Aylık planların değerlendirmesini yapamıyorum & 1 \\
Günlük ve aylık planları bir dönemde 2 kere yani 2 & 1 \\
ayda bir yapıyorum & \\
Böyle bir tecrübem yok & 1 \\
\hline
\end{tabular}

Ayrıca Tablo 2, 3, 4, 5, 7 ve 11 incelendiğinde hazır plan kullandığını söyleyen öğretmenlere karşın sadece 1 öğretmenin değerlendirmeyle ilgili "Böyle bir tecrübem yok” demesi diğer bütün öğretmenlerin değerlendirme yaptığını işaret etmektedir. Fakat Tablo 5'e göre hazır plan kullanan öğretmenlerin yarısından fazlasının 2 planla çalıştığı görülmüştür. $\mathrm{Bu}$ duruma göre, öğretmenlerin resmi olarak kullandıkları planlarla uygulama yaptıkları etkinlikler birbirinden farklı iken değerlendirme kısımlarını hangi plana göre doldurdukları konusunda fikir yürütmeyi engellemektedir.

Tablo 15 incelendiğinde "Değerlendirmelerinizde ölçüt aldı̆̆ınız durumlar nelerdir?" sorusuna öğretmenler "Kendimi, çocukları ve programı değerlendiriyorum, kazanımlara göre değerlendiriyorum, amaç-kazanımlarla ilgili başarılarına bakıyorum" şeklinde cevaplamışlardır. Buna göre Ö.1'in "amaç-kazanım” demesi hâlâ 2006 okul öncesi eğitim programının etkisinden çıkılamadığını düşündürmektedir. "Böyle bir tecrübem yok" diyen ve meslekteki ilk senesinde olan Ö.10 devamında "Teorik olarak bakarsam kazanım ve göstergelerin sınıfın \%80’i başardıysa değerlendirir, bir sonraki aya ona göre alırım." şeklinde cevaplamıştır. Bu duruma göre teorikte bilinen bilgilerin uygulamaya geçirilmediği görülmüştür. Ayrıca verilen teorik bilginin 2013 Okul Öncesi Eğitim Programında olmaması teorik bilgide de eksiklikler olduğunu düşündürmektedir. "Sarmal bir program kazanım ve göstergelerin süreç boyunca, ihtiyaç duyulduğu durumlarda farklı etkinlikler aracılığıyla tekrar tekrar ele alınmasını gerektirir. Böyle yapıldığında kazanımların gerçekleşmesi, pekiştirilmesi ve kalıcılığının sağlanması mümkün olur (MEB, 2013).” Bu özellikten yola çıkarak, öğretmenlerin, çocuklarda pekiştirmek istedikleri davranışlara yönelik her ay aynı kazanımları alarak, plan yapmaları gerektiği söylenebilir. 
Tablo 15

Öğretmenlerin “değerlendirmelerinizde ölçüt aldığınız durumlar nelerdir?” sorusuna verdikleri cevaplar

\begin{tabular}{ll}
\hline Cevaplar & $\mathrm{f}$ \\
\hline Kendimi, çocukları ve programı değerlendiriyorum & 3 \\
Kazanımlara göre değerlendiriyorum & 3 \\
Amaç- kazanımlarla ilgili başarılarına bakıyorum & 1 \\
Yanlışlarını görüp kitaplarda başa dönüyorum & 1 \\
Çocuklardan dönütlere & 1 \\
Çocuklara uygunluğuna & 1 \\
Ne kadar fayda sağladı & 1 \\
Kavramlara göre & 1 \\
Böyle bir tecrübem yok & 1 \\
Çocukların bireysel özelliklerine bakıyorum & 1 \\
\hline
\end{tabular}

\section{4. “Programların Kıyaslanması” Temasına İlişkin Bulgular ve Sonuçlar}

Tablo 16'da görüldüğü üzere "Diğer okul öncesi eğitimi programlarıla kıyasladığınızda hangi MEB programının daha nitelikli olduğunu düşünüyorsunuz?” sorusuna "2013 Okul Öncesi Eğitimi Programı, 2006 Okul Öncesi Eğitimi Programın, program tercih etmeyen" şeklinde cevaplar verilmiştir.

Tablo 16

Öğretmenlerin "diğer okul öncesi eğitimi programlarıla klyasladı̆̆ınızda hangi MEB programının daha nitelikli olduğunu düşünüyorsunuz?” sorusuna verdikleri cevaplar

\begin{tabular}{ll}
\hline \multicolumn{1}{c}{ Cevaplar } & $\mathrm{f}$ \\
\hline 2013 Okul Öncesi Eğitimi Programı & 8 \\
2006 Okul Öncesi Eğitimi Programı & 2 \\
Program tercih etmeyen & 2 \\
\hline
\end{tabular}

Tablo 16’ya göre 2013 Okul Öncesi Eğitimi Programını 8 öğretmen tercih etmiştir. Tablo 17 incelendiğinde araştırmaya katılan öğretmenlerin konu ile ilgili görüşleri şu şekildedir: "Kendini geliştirmiş, koşturmuyoruz, rahat, çok yönlü, ayrıntılı, enerjimiz oluyor, okulun şartlarına uygun olmayabiliyor, MEB yeterli imkân sağlamıyor, köşeleri oluşturmada yeterli materyal ve ortam yok, Çevresel imkânlara ihtiyaç duyuyor, planlar anlaşılmadı, sınıflar aynı standarda getirilmeli”. Her öğretmen 2013 Okul Öncesi Eğitim Programı hakkında farklı düşünceler belirterek programın sadece olumlu özelliklerinden bahsetmeyip, geliştirilmesi gereken özelliklerine de değinmişlerdir. 
En dikkat çeken cevaplar ise Ö.10'un “MEB yeterli imkân sağlamıyor” ve Ö.6’nın "Planlar anlaşılmadı, sınıflar aynı standarda getirilmeli, planla gerçekler arasında büyük fark var.” şeklinde verilen cevapları olmuştur. Verilen bu cevaplardan anlaşıldığı gibi öğretmenler okul öncesi eğitimi sınıflarının daha verimli olmasını ve imkânların geliştirilmesini istemektedirler. Verilen bir başka cevapta Ö.10, "Köşeleri oluşturmada yeterli materyal ve ortam yok" demiştir. Güncellenen programda ' 'ilgi köşeleri” öğrenme merkezleri olarak ifade edilmiştir (MEB, 2013). Başka bir cevapta ise Ö.8 "MEB'de hızlı geçiliyor (bir tema, bir sohbet çabuk geçiyor)" demiştir. Hâlbuki programın temel özelliklerinden bazıları şu şekildedir; Okul öncesi eğitimde, kazanım ve göstergelerin kazandırılmasında konu veya tema merkezli eğitim söz konusu değildir ancak eğitim süreci planlanırken çeşitli konulardan yararlanılabilir. Burada asıl amaç, ele alınan konunun öğretimi değil o konu yardımı ile kazanım ve göstergelerin gerçekleştirilmesidir (MEB, 2013). Öğretmenin, ortaya çıkabilecek günlük ve anlık değişimlere göre eğitim sürecinde gerekli düzenlemeler yapabilmesine firsat vermektedir. Bu programı kullanan öğretmen eğitim planlarını kendisi hazırlar, uygular ve değerlendirir (MEB, 2013a). Bu iki durum, 2006 planının etkisinden çıkılamadığını işaret ederken "Planlar anlaşılmadı" cevabını doğrulamaktadır.

Tablo 16’ya göre 2 öğretmen (Ö.2 ve Ö.9) 2006 Okul Öncesi Eğitimi Programını öğretmen tercih etmiştir. Tablo 18 incelendiğinde "2006 Okul Öncesi Ĕgitimi Programını Tercih Etme Nedenleri” şöyledir "Daha doluydu, daha fazla etkinlik yapılıyordu, yeni program az sayıda öğrenci olan gruplarda daha verimli, Yeni programda sinıfta tek öğretmen oluyor böyle olunca uygulanabilirliği pek olmuyor”.

Tablo 16'ya göre 2 öğretmen (Ö.3 ve Ö.4) program tercih etmemişlerdir. Tablo 19'a göre "Program Tercih Etmeme Nedenleri" şu şekildedir "2013 programının program olduğunu düşünmüyorum. MEB'de okul öncesi eğitim programı yok. Oyun saatine bile ne kadar zaman ayrılacağı yazmıyor, Aile evi ziyaretleri önceden zorunlu değildi, portfolyo sunumu oldu bu okul öncesi için çok iyi değil" şeklinde olmuştur. En dikkat çeken Ö.3'ün, “2013 programının program olduğunu düşünmüyorum. MEB'de okul öncesi eğitim programı yok. Oyun saatine bile ne kadar zaman ayrılacağı yazmıyor” şeklindeki verdiği cevaptır. 2013 Okul Öncesi Eğitim Programının temel özelliklerinden bir tanesi esnek olmasıdır. Buna bağlı olarak, anlık değişimlere göre eğitim sürecinde gerekli düzenlemeler yapabilmesine firsat vermektedir (MEB, 2013). 
Tablo 17

2013 Okul Öncesi Eğitimi Programını tercih etme nedenleri

\begin{tabular}{lc}
\hline \multicolumn{1}{c}{ Cevaplar } & $\mathrm{f}$ \\
\hline Koşturmuyoruz, rahat, çok yönlü, ayrıntılı, enerjimiz & 1 \\
oluyor, etkinlik yetiştirmeye çalışmıyorum. & \\
Dört dörtlük değil ama yine de revize edilmiş, okulun ve & \\
çocukların şartlarına uygun olmayabiliyor, firsat eğitimine & 1 \\
dönüştürülebiliyor & \\
Öğretmeni rahatlatıyor, bizim eğitim sistemimize uymuyor & \\
ve alt yapı yok, diğer programlar daha zor ve yıpratıcı, & \\
esnek bir plan, çevresel imkânlara ihtiyaç duyuyor, planlar & \\
anlaşılmadı, sınıflar aynı standarda getirilmeli, sınıfın fiziki & \\
koşulları engelliyor, her çocuğun aynı şeyleri öğrenmesi & 1 \\
bekleniyor, sınıfların küçük olması, çocuğun yeteri kadar & \\
dolaşacak alanı olmaması, planla gerçekler arasında büyük \\
fark var.
\end{tabular}


Tablo 18

2006 Okul Öncesi Eğitimi Programını tercih etme nedenleri

\begin{tabular}{lc}
\hline \multicolumn{1}{c}{ Cevaplar } & $\mathrm{f}$ \\
\hline Daha doluydu & 1 \\
$\begin{array}{l}\text { Daha fazla etkinlik yapılıyordu } \\
\text { Yeni programda değerlendirme kısımlarını }\end{array}$ & 1 \\
yaparken sıkılma oluyor ve ilgileri dağılıyor & 1 \\
Yeni program az sayıda öğrenci olan & \\
gruplarda daha verimli & 1 \\
Yeni program çok fazla materyale ihtiyaç & \\
duyuyor & 1 \\
Yeni programda sınıfta tek öğretmen oluyor, \\
böyle olunca uygulanabilirliği pek olmuyor \\
$\begin{array}{l}\text { Eski program daha standarttı } \\
\text { Eski program daha açıtı } \\
\text { Eski programda güzel bir şekilde, bütün } \\
\text { etkinlikler daha doğru uygulanabiliyordu }\end{array}$ \\
\hline
\end{tabular}

Tablo 19

Program tercih etmeme nedenleri

\begin{tabular}{ll}
\hline Cevaplar & $\mathrm{f}$ \\
\hline 2013 programının program olduğunu düşünmüyorum. MEB'de & \\
okul öncesi eğitim programı yok. Oyun saatine bile ne kadar zaman & 1 \\
ayrılacağı yazmıyor & \\
Yeni program çok genel ve kabataslaktır & 1 \\
En son programda bayağı değişiklikler oldu & 1 \\
Aile evi ziyaretleri önceden zorunlu değildi & 1 \\
Portfolyo sunumu oldu, bu okul öncesi için çok iyi değil & 1 \\
\hline
\end{tabular}




\section{Sonuç ve Tartışma}

Bu araştırmada 2013 Okul Öncesi Eğitim Programının sunduğu özelliklerine göre etkinlikplanlarınıniçeriği,hazırlanışıveuygulanışınınöğretmenlerindeğerlendirmelerine göre incelenmesi amaçlanmıştır. Bu ana amaç doğrultusunda, "2013 Okul Öncesi Eğitim Programının içeriği hakkında öğretmenlerin değerlendirmeleri nelerdir? Etkinlik planı hazırlanırken dikkat edilen noktalar nelerdir? Yazılan etkinlik planlarıyla uygulama arasında fark var mıdır?" sorularına cevap aranmıştır. Araştırmanın çalışma grubunu oluşturan öğretmenlerin yarısından fazlası, orta düzey sosyo-ekonomik profili temsil eden okullarda çalışmaktadır.

Araştırma verileri incelendiğinde, "2013 Okul Öncesi Eğitim Programına göre öğretmenler planlama sürecini nasıl değerlendirmektedir?” ve “Geçmişten günümüze okul öncesi eğitim programları kıyaslandığında, öğretmenler hangi MEB programını daha nitelikli olduğunu düşünmektedirler? Dayanakları nelerdir?” sorularını "Planlama süreci" ve "Programların kıyaslanması" temalarında değinilmiştir. Buna göre öğretmenlerin çoğu 2013 Okul Öncesi Eğitim Programından memnun kalırken, geliştirilmesi gereken özelliklerine de değinmişlerdir. Olumlu özellikleri arasında "Koşturmuyoruz, rahat, çok yönlü, ayrıntılı", "Öğretmeni rahatlatıyor, esnek", "Gerçekçi, uygulanabilir, öğrenci merkezli, pratik”, "Geniş, kapsamlı, dolgun, kendini geliştirmiş" gibi ifadeler öne çıkarken; geliştirilmesi gereken özellikler şu şekilde sıralanmıştır: "Okulun ve çocukların şartlarına uygun olmayabiliyor.”, "Bizim eğitim sistemimize uymuyor ve alt yapı yok, çevresel imkânlara ihtiyaç duyuyor, planlar anlaşılmadı, sınıflar aynı standarda getirilmeli, planla gerçekler arasında büyük fark var.", "MEB yeterli imkân sağlamıyor, köşeleri oluşturmada yeterli materyal ve ortam yok.", "Sınıftaki çocukların yaş gruplarının farklı olması", "Planın tamamını yazmak zor geliyor.", "Uyarlama kısmında", "Süre planlanmasında", "Hangi ayda hangi kazanım- göstergelerin kullanılacağının belirlenmesi”. Ayrıca araştırmacılar görüşme yapma amacıyla gittikleri anasınıflarında şu sorunları gözlemlemişlerdir: "fiziksel ortamın ve materyallerin yetersizliği, materyallerin uygun seçilmemesi (özellikle çok renk kullanılarak sınıfların dekore edilmesi, bazı sınıflarda ilkokul sınıflarında olduğu gibi yerden çok yüksekte $120 \times 240 \mathrm{~cm}$ boyutunda yazı tahtasının bulunması), sınıf mevcudunun fazla olması ve kaynaştırma öğrencilerinin 1 kişiden fazla olması, sınıftaki öğrencilerin yaş aralığının fazla olması”. Verilen bu cevaplar ve araştırmacının gözlemeleri göz önüne alındığında 2013 Okul Öncesi Eğitim Programının plan yazarken sunduğu firsatlar ve geliştirilmesi gereken özelliklerinin yanında "köşe, tema, kazanımgöstergelerin toplu yazılması, amaç-kazanım” gibi cevapların alınması öğretmenlerin 2006 Okul Öncesi Eğitim Programının etkisinden çıkamadıklarına işaret etmektedir. Ayrıca "kazanım-göstergelerin hangi ayda kullanılacağının bilinmemesi, süre planlamasının programda olmaması" gibi verilen bu cevaplardan da 2013 programının tam olarak anlaşılamadığını düşündürmektedir. Dilek’in (2016) yaptığı araştırmada da 
benzer sonuçlar elde edilmiştir. Köksal, Balaban Dağal ve Duman'a (2016) göre ise bu durum hizmet içi programlarla desteklenip programın daha iyi anlaşılması sağlanabilir.

Eğitim planı hazırlayan yayınevlerinin ilk hedefi, eğitim setlerinin satışını arttırmak olduğu düşünülürse (Alabay ve Yağan Güder, 2015); çalışma grubundaki öğretmenlerin doğrudan ve dolaylı olarak hazır plan kullandıkları sonucuna ulaşılmıştır. 12 öğretmenden 5'i doğrudan, daha görüşmenin başında "hazır plan kullanıyorum" şeklinde kendilerini ifade etmişlerdir. Diğer öğretmenler ise bazı sorularda hazır plan kullandıklarını söyleyerek görüşme sırasında kendileriyle ilgili objektif davranmadıkları anlaşılmıştır. Ayrıca bazı öğretmenler hiçbir çekincede bulunmadan, hazır plan kullandıklarını fakat araştırmacıya bunu yazmaması gerektiğini söyleyip, programda olması gerektiği gibi cevaplayacaklarını söylemişlerdir.

Hazır plan kullanma sebeplerinin neler olduğu incelendiğinde elde edilen veriler şu şekildedir: "Zorlandığım nokta yok, fiziksel ortamın uygun olmaması, malzemelerin uygun olmaması, sınıftaki çocukların yaş gruplarının farklı olması, hazır plan kullanıyorum, planın tamamını yazmak zor geliyor, uyarlama kısmında, süre planlanmasında, merkezleri oluşturmada, hangi ayda hangi kazanım- göstergelerin kullanılacağının belirlenmesinde zorlanıyorum". Buradan da anlaşılacağı gibi öğretmenlerden bazıları "Zorlandığım nokta yok" demelerine rağmen hazır plan kullandıklarını belirtmişlerdir. Bazı öğretmenler ise hazır plan kullanma sebeplerini bile açıklamamışlardır.

Demir Yıldız ve Dönmez'in (2017) aktarımıla, Bronfenbrenner'in Ekolojik Sistemler Kuramına göre mikrosistem, bireyin gelişimini en hızlı ve doğrudan etkileyen grupları ve kurumları ifade eder. Mikrosistem de bulunan okul öncesi öğretmenlerinin kamu kurumlarında çalışma rutinleri ise şu şekildedir. Ders yılı süresinin 180 iş gününden az olmaması esastır. Günde ellişer dakikalık aralıksız 6 etkinlik saati süre ile ikili eğitim yapılır. (MEB, 2014). MEB'in yönetmeliğine göre aralıksız eğitim veren okul öncesi öğretmenleri; günlük olarak merkezleri düzenleyip uygun materyal temin etmeli, aylık plandaki kazanım ve göstergelere uygun etkinlik araştırıp etkinlik planı formatına döküp, etkinliğe uygun materyalleri temin edip, o gün uyguladıkları planın değerlendirmesini yapmalıdırlar. Ayrıca her ay, aylık plan ve diğer işler (gelişim gözlem raporlarının doldurulması, veli toplantısı, alan gezilerinin düzenlenmesi, sınıfa konuk çağırma, okul toplantıları, okulun beklentileri...) için ekstra zaman ayırmalıdırlar. Bu da yukarıda bahsedilen çalışma saatleri içerisinde yapılması gerekmektedir. Buna bağlı olarak, öğretmenlerin hazır plan kullanma sebepleri arasında "planın tamamını yazmak zor geliyor" cevabı bu durumu doğrular niteliktedir.

"Okul öncesi öğretmenleri plan hazırlama süreçlerinde okul yönetiminin tutumunu nasıl değerlendirmektedirler?” ve “Okul öncesi öğretmenleri aylık ve günlük planlarının değerlendirmesini hangi sıklıkla yapmaktadırlar ve ölçüt aldığı durumlar nelerdir?" problem sorularını "Planlama süreci", "Okul yönetiminin tutumu" ve "Değerlendirme" temalarında değinilmiştir. Buna göre, öğretmenlerin her soruda verdikleri farklı ve çelişkili cevaplar göz önüne alındığında çoğu öğretmenin hazır planı 
uygulamaya geçirmediği yönünde bir tablo incelenmiştir. Öğretmenlerin yarısından fazlasının iki planla çalıştı̆ıını düşündürtmektedir. Birinci planın resmi evrak olarak gösterildiği -ki bu hazır plan olabilir-, ikinci planın ise yazıya geçirilmemiş ama öğretmenin sınıfta uyguladığı asıl etkinliklerden oluştuğu işaret etmektedir. Bu durum çocukların gelişimlerinin profesyonel, düzenli ve sistematik olarak değerlendirilmesi açısından ciddi sorunlar taşımaktadır. Öğretmenlerin resmi evrak kaygısıyla hazır plan kullanmalarının sebebi Millî Eğitim Bakanlığı Eğitim ve Öğretim Çalışmalarının Plânlı Yürütülmesine İlişkin Yönergesinin 6. maddesiyle ilişkili olduğu söylenebilir; "Eğitimöğretim kurumlarında eğitim etkinliklerine ve derslere hazırlıklı girmek yasal yönden zorunlu, eğitsel yönden gereklidir". Bununla birlikte denetim mekanizmalarından biri olan okul yönetiminin eğitim planlarını incelemeden imzalaması okul öncesi eğitimde plan yapmaya verilen önem ile ilgili düşündürücü bir tablo çizmektedir. MEB 2013 Okul Öncesi Eğitim Programı'nın temel özelliklerinden olan esneklik, öğretmenlere başka kaynaklardan yararlanma, planda olan herhangi bir değişikliğin değerlendirme kısmına yazılma imkânı sağlaması göz önünde bulundurulduğunda, öğretmenlerin planlama ve değerlendirme süreciyle ilgili eski programlara göre daha öğretmen dostu bir sistemde çalışıkları anlaşılmıştır. Programın aksine, araştırma sonuçlarına göre ve görüşme sırasında öğretmenlerin araştırmacılara "Ben olması gerektiği gibi söyleyeyim.” demeleri öğretmenlerin çoğunun hiç değerlendirme yapmadığı ya da beklenilen süre içerisinde yapmadıklarıyla ilgili sonuçları ortaya koymaktadır. Ayrıca öğretmenlerin resmi olarak kullandıkları planlarla, uygulamada kullandıkları etkinlikler birbirinden farklı iken değerlendirme kısımlarını hangi plana göre doldurdukları bilinmemektedir. Bu sonuç, öğretmenlerin neyi ne kadar yaptıklarıyla ilgili analizi zorlaştırmaktadır. Aslında öğretmenlerin "Ben olması gerektiği gibi söyleyeyim." ifadeleri, amaçlı- bilinçli ve planlı bir şekilde eğitim süreçlerini yönetmediklerine dair yargıları güçlendirmektedir.

Belirtilen durumların önemli bir sorun olduğunun öğretmenler farkında değillerdir ya da objektif davranmaktan kaçınmışlardır. Bu sonuca "Ben olması gerektiği gibi söyleyeyim." cümlesinden ve öğretmenlerin her soruya verdikleri çelişkili cevaplardan ulaşılmıştır. Bu çalışmada, öğretmenlerin görüşme sorularına verdikleri cevaplardaki tutarsızlıktan yola çıkarak plan hazırlama süreçlerinde yararlandıkları kaynaklar incelendiğinde internet, kitap ve eski tecrübeler ön plana çıkmaktadır. Eray Alışkan ve Güneyli'nin (2016) çalışmasında ise internet en son sırada tercih edilen kaynak olarak belirtilmiştir. Çalışma grupları arasındaki sayısal dengesizlik ve araştırmaların yapıldığı yerlerin farklı olmasından kaynaklarda değişikliğe sebep olabilir. 


\section{Öneriler}

Araştırma sonuçları doğrultusunda şu önerilerde bulunabilir:

- Nitelikli bir okul öncesi eğitim ve çalışma şartlarının diğer okul kademelerine göre daha farklı oluşundan dolayı okul öncesi eğitim, Milli Eğitim Bakanlığı Temel Eğitim Genel Müdürlüğünden ayrılmalı ve Milli Eğitim Bakanlığı Okul Öncesi Eğitim Genel Müdürlüğü kurulmalıdır.

- Eğitim programlarının çok fazla değişmesi öğretmenlerin yeni programa uyum olmasını zorlaştırdığı için dönemin şartlarına göre güncellenmesi dışında verilen eğitimin baştan sona her seferinde değiştirilmemesi önerilmektedir.

- Okul öncesi öğretmenlerinin mola veya teneffüsü olmadan bütün gün çalışmaları ve çocukların yaşlarının küçük olmasından kaynaklı sınıfı tek bırakılamaması gibi durumlar göz önüne alınırsa gün içerisinde öğretmenlerin temel ihtiyaçlarını karşılayabilecekleri bir zaman bile olmamaktadır. Ayrıca MEB'in okul öncesi öğretmenlerinden beklediği; merkezlerin düzenlenmesi, günlük planların yazılması ve değerlendirilmesi, aylık plan ve diğer işlerin (gelişim gözlem raporlarının doldurulması, veli toplantısı, alan gezilerinin düzenlenmesi, sınıfa konuk çağırma, okul toplantıları, okulun beklentileri...) yapılması içinde belli bir zamana ihtiyaç vardır. Buna göre çalışma şartları ve saatleri düzenlenebilir ayrıca her sınıfta öğretmen dışında -isteğe bağlı olarakbir de yardımcı olması önerilmektedir. Böylece öğretmenin daha verimli olacağ1 düşünülmektedir.

- Performans değerlendirme ölçütlerine göreöğretmen maaşları düzenlenebilir. Böylelikle verimli çalışan veya çalışmayan öğretmen aynı maaşı almayarak, çalışma teşviki sağlamak mümkün olabilir.

- Tüm Türkiye'deki okul öncesi eğitim sınıflarının ve okullarının uygun bir şekilde fiziksel ve materyal bakımından eşitlenmesi sağlanabilir.

- Okul öncesi eğitim sınıflarında yaş grubu olarak karma eğitim sistemi azaltılabilir. Sınıfta küçük yaş grubundan fazla çocuk olursa diğer çocukların gelişimsel ihtiyaçlarına yönelik çalışmaların sayısı ve niteliği azalmaktadır.

- Okul öncesi eğitim sınıflarının 15 kişiden fazla olmaması verimli bir eğitim için önerilmektedir. 


\section{Kaynakça}

Alabay, E. ve Yağan Güder, S. (2015). Hazır planlarda yer alan fen etkinliklerinin okul öncesi eğitim programı temel özellikleri açısından incelenmesi. Uluslararası Eğitim Bilimleri Dergisi. 4, 1-21.

Altınkurt, Y. ve Yılmaz, K. (2014). Öğretmenlerin mesleki profesyonelliği ile iş doyumları arasındaki ilişki. Sakarya University Journal of Education, 4(2), 57-71.

Alvestad, M., \& Duncan, J. (2006). “The value 1s enormous - 1t's priceless 1 think!” new zealand preschool teachers' understandings of the early childhood curriculum in new zealand- a comparative perspective. International Journal of Early Childhood, 38(1), 31-45.

Avc1, N. (2014). Tüm çocuklarla çalışmak: birlikte eğitim/ kaynaştırma. N. Avc1 ve M. Toran (ed.), Okul Öncesi Eğitime Giriş (ss. 260). Ankara: Eğiten Kitap.

Balc1, A., Gündoğdu, K. ve Çelik, N. (2012). Okul öncesi eğitim programına ilişkin bir ihtiyaç analizi çalışması. Adnan Menderes Üniversitesi Eğitim Fakültesi Eğitim Bilimleri Dergisi, 3(1), $10-24$

Cüceloğlu, D. ve Erdoğan, İ. (2013). Öğretmen Olmak. İstanbul: Final Kültür Yayınları.

Dağlığlu, E. (2010). Erken çocukluk dönemi öğretmeninin özellikleri. İbrahim Halil Diken (ed). Erken Çocukluk Ĕgitimi (ss. 482- 515). Ankara: Pegem Akademi.

Demir Yıldız, C. ve Dönmez, B. (2017). Ekolojik sistemler kuramı çerçevesinde yöneticilerin karar verme davranışını etkileyen faktörlerin incelenmesi. International Periodical for the Languages, Literature and History of Turkish or Turkic, 12(28), 223-244. doi:http://dx.doi.org/10.7827/ TurkishStudies. 12328

Demirel, Ö. (2013). Program geliştirmede temel kavramlar. Eğitimde Program Gelişstirme Kuramdan Uygulamaya (ss. 1- 8). Ankara: Pegem Akademi.

Dilek, H. (2016). T.C. MEB 2013 okul öncesi eğitim programı ile 2006 programının karşılaştırılması. Ö. Demirel ve S. Dinçer (Ed.). Eğitim bilimlerinde yenilikler ve nitelik arayışı (2. Baskı) içinde s. 585-604. Ankara: Pegem Akademi.

Eray Alışkan, E. ve Güneyli, A. (2016). Okul öncesi öğretmenlerinin Türkçe dil etkinliklerine ilişkin görüşleri: lefkoşa örneği. Ana Dili Eğitimi Dergisi, 4(3), 348-371.

Gültekin Akduman, G. (2010). Okul öncesi eğitimin tanımı ve önemi. Gülden Uyanık Balat (ed). Okul öncesi eğitime giriş içinde ss. 2-15. Ankara: PegemA Yayıncılık.

Gürkan, T. (2003). Okul öncesi eğitim programının temel özellikleri. Ne yapıyorum? Neden yapıyorum? Nasıl yapmalıyım? ss. 98- 104. İstanbul: YA- PA.

Gürkan, T. (2010). Okul öncesi eğitim programı. Rengin Zembat (ed). Okul Öncesinde Özel Ögrretim Yöntemleri (ss. 35- 60). Ankara: Anı Yayıncılık.

Güven, G. (2010). Okul öncesi eğitim programı. Gülden Uyanık Balat (ed.) Okul Öncesi Eğitime Giriş içinde (ss. 82-113). Ankara: Pegem Akademi.

Kandır, A. (1999). Okul öncesi eğitim kurumlarında etkinliklerin planlanması. Gazi Üniversitesi Anaokulu/ Anasınıfi Öğretmen El Kitabı (ss. 82- 90). İstanbul: YA- PA. 
Kandır, A., Özbey, S. ve İnal, G. (2007). Okul öncesi öğretmenlerinin eğitim programlarını planlanma ve uygulamada karşılaştıkları güçlüklerin incelenmesi. Uluslararası Sosyal Araştırmalar Dergisi, 2(6), 374-387.

Karataş, Z. (2015). Sosyal bilimlerde nitel araştırma yöntemleri. Manevi Temelli Sosyal Hizmet Araştırmaları Dergisi 1(1), 62-80.

Koçyiğit, S. (2010). Okul öncesi eğitim kurumlarında personel. Gülden Uyanık Balat (Ed.). Okul Öncesi Eğitime Giriş içinde (ss. 184-201). Ankara: Pegem Yayıncılık.

Köksal, O., Balaban Dağal, A. ve Duman, A. (2016). Okul öncesi öğretmenlerinin okul öncesi eğitim programı hakkındaki görüşlerinin belirlenmesi. The Journal of Academic Social Science Studies (46), 379- 394.

Miles, M, B., \& Huberman, A. M. (2016). Qualitative data analysis: An expanded sourcebook (2nd ed.). Thousand Oaks, CA: Sage.

Milli Eğitim Bakanlığı Temel Eğitim Genel Müdürlüğü (2013). Okul Öncesi Eğitim Programı. Ankara.

Milli Eğitim Bakanlığı Eğitim ve Öğretim Çalışmalarının Plânlı Yürütülmesine İlişkin Yönerge (2013a). Erişim tarihi: 24.10.2019, http://mevzuat.meb.gov.tr/html/2551_0.html

Milli Eğitim Bakanlığı Okul Öncesi Eğitim ve İlköğretim Kurumları Yönetmeliği (2014). Erişim tarihi: 24.10.2019, http://mevzuat.meb.gov.tr/html/ilkveokuloncyon_0/yonetmelik.pdf

NBPTS, (2016). The national boad for professional teaching standards. what teachers should know and be able to do. Erişim tarihi: 25.09.2019, http://accomplishedteacher.org/wp-content/ uploads/2016/12/NBPTS-What-Teachers-Should-Know-and-Be-Able-to-Do-.pdf

Özdemir, M. (2010). Nitel veri analizi: sosyal bilimlerde yöntembilim sorunsalı üzerine bir çalışma. Eskişehir Osmangazi Üniversitesi Sosyal Bilimler Dergisi, 11(1), 323- 343.

Raelin, J. A. (1999). Kamuran, kültürlerin çatışması (yönetenler-yönetilenler) (K. Tuncay, Çev.) İstanbul: Türkiye İş Bankası Kültür Yayınları.

Trawick-Swith, J. (2013). Erken çocukluk döneminde gelişim [çok kültürlü bir baklş açısı] (B. Akman, Çev.) Ankara: Nobel Akademik Yayıncılık.

Tuncer, B. (2015). Okul öncesi eğitimdeki çağdaş yaklaşımların incelenmesi ve meb okul öncesi programıla karşılaştırılması. International Journal of Field Education, 1(2), 39-58.

Ünver, G. ve Erdamar, G. (2015). Türkiye'de erken çocukluk dönemi öğretmenlerinin eğitim programı geliştirme sürecine katkıları. Ahi Evran Üniversitesi Kırşehir Eğitim Fakültesi Dergisi (KEFAD), 16(1), 215-234.

Yıldırım, A. ve Şimşek, H. (2013). Sosyal Bilimlerde Nitel Araştırma Yöntemleri. (Genişletilmiş 9. Baskı). Ankara: Seçkin Yayınları.

Yirci, R. (2017). Öğretmen profesyonelliğinin önündeki engeller ve çözüm önerileri. Ahi Evran Üniversitesi Kırşehir Eğitim Fakültesi Dergisi (KEFAD), 18(1), 503-522. 